\title{
A Combined Water Management Approach Based on River Water Quality Standards
}

\author{
H. Hoppe ${ }^{*}$, M. Weilandt and H. Orth \\ Ruhr University of Bochum, Institute of Environmental Engineering, 44780 Bochum, Germany
}

\begin{abstract}
The objective of the research project described was to develop a combined water management approach for a catchment area, including the sewage system, the wastewater treatment plant (WWTP), and the receiving water. The combined approach was designed to provide both "good water quality" - as defined in the European Water Framework Directive - and cost savings. The investigations were carried out in Odenthal, a small municipality $(12,500$ p.e.) in the river Dhünn catchment in the western part of Germany. Emphasis was placed on investigation of the impact on the receiving water of pollution resulting from discharges at stormwater overflow tanks (SOTs), combined sewer overflows (CSOs) and the WWTP. These structures are the interface between the urban wastewater system and the receiving water bodies. The river water quality standards applied were deduced from an intensive monitoring program relating to the sewer system, the WWTP and the river and creeks. Specific threshold concentrations for ammonia, dissolved oxygen and nitrite were defined, depending on the frequency of occurrence and the duration of the overflow from SOTs and CSOs. The higher planning costs, primarily the cost of the monitoring program, were compensated for by cost savings relating to the construction of SOTs and the WWTP. In total, considerable cost savings were achieved in comparison to the previous separate design of the sewer system and the WWTP. The present emission-based regulations imposed - in this case study - more restrictive requirements and resulted in higher final systems costs than would have been the case if the costs had been on the requirements deduced from the biological analyses of the receiving water data.
\end{abstract}

Keywords: Combined sewer overflow, integrated modelling, receiving water, river water quality standards, stormwater overflow tank, wastewater treatment plant, water management

\section{Introduction}

Combined water management approaches - regarding the sewer system, the WWTP and the receiving water - are becoming more and more important (Crabtree et al., 1998; FWR, 1998 \& Schütze et al., 2002). Recent case-studies, e.g. Grüning \& Orth (2001a,b), Grüning et al. (2002), Mark et al. (1999) and Vollertsen et al. (2002), have highlighted the advantages of integrated control strategies. New simulation and optimization tools have been developed in this context (e.g. Rauch et al., 2002; Schütze et al., 1999). Nevertheless, the implementation of combined water management approaches using standard instruments - existing models and measurements - is rare (Harremoës, 2002).

Additionally, as regards the design of structures (e.g. overflows and stormwater tanks), many planning standards applied today to protect receiving waters from discharges from urban wastewater systems are emission standards (effluent standards). Local circumstances and the demands of the receiving water could be taken into account more appropriately, if river water quality standards (receiving water standards, environmental quality standards (FWR,

\footnotetext{
* Corresponding author: email@holgerhoppe.de
}

1998), immission based standards) were also applied (e.g. WFD, 2000). River water quality standards describe concentrations, which must be achieved in the receiving water. But, as regards river water quality standards, there is still lack of knowledge and data with regard to methods of selecting combinations of measures in terms of a combined water management approach (Chocat et al., 2001; Langeveld et al., 2002).

Taking these thoughts into account, a research project was launched to develop and apply an approach that permits an immission-oriented assessment of the impact of discharges from the combined sewage system (immissionbased approach). The developed approach presented in this paper is based on an extensive collection of data and readings in the drainage area, the sewage system, the WWTP, and the receiving waters in the area of the municipality of Odenthal (Germany). The emphasis was laid on an investigation of the impact of discharges from combined sewer overflows, stormwater overflow tanks and the WWTP. To determine the permissible water pollution load, concentrations meeting the requirements for a body of salmonidspawning water were inferred with respect to dissolved oxygen, nitrite, and ammonia content. These threshold concentrations (guide-values) were to be defined relative to exposure periods and frequency of occurrence. 


\section{Description of the Project Area}

The municipality of Odenthal, with a catchment basin of roughly $40 \mathrm{~km}^{2}$, is situated in the Bergische Land area in North Rhine-Westphalia, Germany. The terrain of the municipality is characterized by grassland and wooded areas. The main receiving stream, with a mean low water flow of $1 \mathrm{~m}^{3} / \mathrm{s}$, is the Dhünn, which is dammed up to provide drinking water supplies upstream of Odenthal. The catchment area of the sewer system covers 319 ha. The residential area is largely drained via a combined sewage system (212 ha). Some relatively small areas of the town, located to the east of the Dhünn and drained by a separate system, are connected to the WWTP by a pressure main. In a few of these small areas the sewage is treated in small domestic sewage treatment plants. These catchment areas will be connected directly to the sewer systems during the next 10 years. Figure 1 gives an overview of the drainage system.

The sewage system as a whole consists of four stormwater overflow tanks (SOTs) with volumes of $95 \mathrm{~m}^{3}$ to
$1500 \mathrm{~m}^{3}$ (total volume $3150 \mathrm{~m}^{3}$, specific volumes of $30 \mathrm{~m}^{3} /$ ha to $100 \mathrm{~m}^{3} / \mathrm{ha}$ ), a retention tank, and five combined sewer overflows (CSOs). The CSOs are designed to reduce high combined wastewater flow rate peaks. Peaks of (less polluted) storm sewage are discharged into the nearby receiving water. According to Standard ATV-A 128E (ATVDVWK, 1992), an overflow into the river has to be avoided at least for rainfall intensities of less than $15 \mathrm{l} /(\mathrm{s} \cdot \mathrm{ha})$. The SOTs provide storage capacity in the combined sewer system for combined sewage during rainfall. The recommended maximum specific volume in economic terms is $40 \mathrm{~m}^{3} / \mathrm{ha}$ (ATV-DVWK, 1992). If a SOT is filled during a rainfall-event, the combined sewage is additionally discharged into the receiving water. The largest of the SOTs in the Odenthal catchment area is located close to the WWTP. Besides being discharged into the Dhünn, combined sewage is also discharged into the three small creeks Leimbach, Waschbach and Schwarzbroicher Bach (Figure 1). The sewage system has no real-time control system.

The WWTP Odenthal (operated by the Wupperverband,

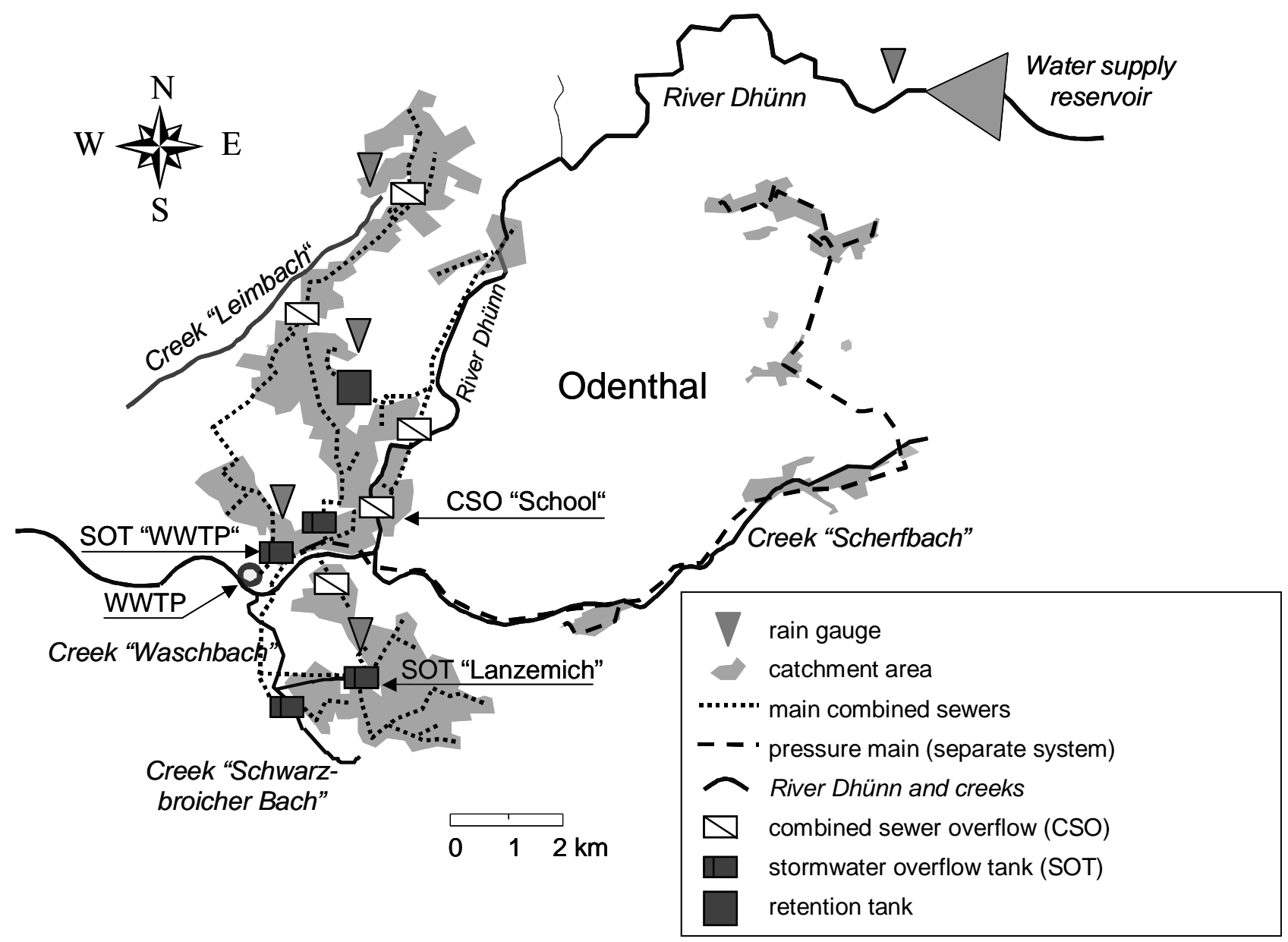

Figure 1. Overview of the drainage system in the Municipality of Odenthal. 
the local association in charge of water quality management) is designed for 12,500 p.e.. Due to the ongoing increase in population, plans are already being made for the expansion of the treatment plant. A detailed description of the project area and the system operation may be found in Orth et al. (2003).

\section{Monitoring-Programs and Data}

The Wupperverband makes routine spot-checks of the Dhünn's water quality at various points at 14-day intervals. In addition, at the WWTP discharge point (combined effluent from the treatment plant and from the SOT "WWTP") and at the CSO "School", the back-ground concentration (COD, BOD 5, TOC, $\mathrm{N}_{\mathrm{TOT}}, \mathrm{NH}_{4}-\mathrm{N}, \mathrm{NO}_{3}-\mathrm{N}, \mathrm{NO}_{2}-\mathrm{N}, \mathrm{PO}_{4}-\mathrm{P}$, $\mathrm{SS}$ and chloride) has been determined in the receiving water upstream of the discharge points, in the form of 15-minute composite samples, for 37 storm sewage overflow events (16 for the CSO "School" and 21 for the SOT "WWTP"). These measurement-programs were carried out from 2000 to 2002. The dissolved oxygen, $\mathrm{pH}$-value, conductivity, and temperature parameters were measured continuously at 5-minute intervals over a 14-month period as part of the measurement-program. A detailed description of the measurement facilities at the combined sewage discharge points may be found in Weilandt et al. (2001).

An evaluation of aerial photos of the municipality formed a basis for determining the overall drainage area. By means of these evaluations it was possible to classify the sizes of the various drainage areas and their utilization. On the basis of these results, the degrees of impermeability were then ascertained, the results being validated by local inspections. The gradient classes of the areas were established by means of a digital model of the terrain. All the data collected were stored in a geographical information system $\left(\right.$ ArcView ${ }^{\circledR}$ ) and used to create a sewer simulation model of the sewage system (ESRI, 2003). In addition, forecast data for the planning periods up to 2010 and 2020 were also drawn upon.

As the existing cadastral plan of the sewage system was incomplete, a consulting company was commissioned by the Wupperverband to carry out extensive follow-up surveying work. A re-survey was conducted especially of all the CSOs and SOTs. To permit the calibration of the sewer simulation model, the flow rate was measured at eight of the CSOs and SOTs and in the three main combined sewers upstream of the WWTP. The water levels of the SOTs were ascertained in addition. Figure 2 provides an overview of these measuring points.

To determine the degree of pollution during dry weather flow (DWF), the COD, $\mathrm{BOD}_{5}, \mathrm{TOC}, \mathrm{N}_{\mathrm{TOT}}, \mathrm{NH}_{4}-\mathrm{N}$, $\mathrm{NO}_{3}-\mathrm{N}, \mathrm{NO}_{2}-\mathrm{N}, \mathrm{PO}_{4}-\mathrm{P}, \mathrm{SS}$, and chloride parameters were recorded (six days, 1-hour composite samples). At the
WWTP and CSO "School" discharge points, 15-minute composite samples (37 storm sewage overflow events) were taken to ascertain the degree of pollution of the storm sewage (the above-mentioned parameters being determined). At the same time, the dissolved oxygen, $\mathrm{pH}$-value, conductivity, and temperature parameters were measured at 5-minute intervals. The quantities of sewer infiltration water were ascertained on the basis of the nightly minima of the readings of the inflow rate into the WWTP, the last five years (1996-2001) being used as a basis. By means of the nightly minima of the readings for the flow rates through the three main sewers, the quantities of sewer infiltration water were able to be assigned to each of the sub-catchment areas belonging to these sewers.

The precipitation was measured continuously (tipping-bucket gauges) at four stations in the catchment area during the project (2000-2002), so that the impact of unequally distributed rainfall was ascertainable.

Alongside ammonium, nitrate and phosphate concentrations and turbidity were also measured online in the WWTP outlet. Inflow and outflow curves were recorded to enable the data obtained to be used to calibrate a dynamic simulation model SIMBA ${ }^{\circledR}$ (IFAK, 2003) for the WWTP based on the Activated Sludge Model No. 1 (ASM 1) of the International Water Association (IWA, 2000).

\section{Evaluation of Threshold Concentrations for the Receiving Water}

First of all, in the course of a preliminary limnological investigation (Podraza et al., 2000), all points of discharge from the separate and combined sewage systems were examined in order to find out whether a comparison of macrozoobenthos colonization upstream and downstream of a discharge point yielded significant differences that were attributable to the sewage discharge.

At three discharge points (combined discharge from the WWTP and the SOT "WWTP", the CSO "School" and the SOT "Lanzemich"), significant changes were detectable. Thereupon, the investigation program was intensified at these points. Both upstream and downstream of the discharge points, the macrozoobenthos population was recorded quantitatively seven times at four-weeks intervals. During the storm sewage overflow events, the background concentrations in the receiving water and the pollutant concentrations in the overflows were measured. Using the flow rates, it was possible to calculate the resulting contamination of the receiving water downstream of the discharge points on the basis of the background pollution and the pollution of the discharged storm sewage. This contamination was then correlated with the results of the macrozoobenthos investigations in order to analyze the links between the contamination and the changes within the biocoenosis. 


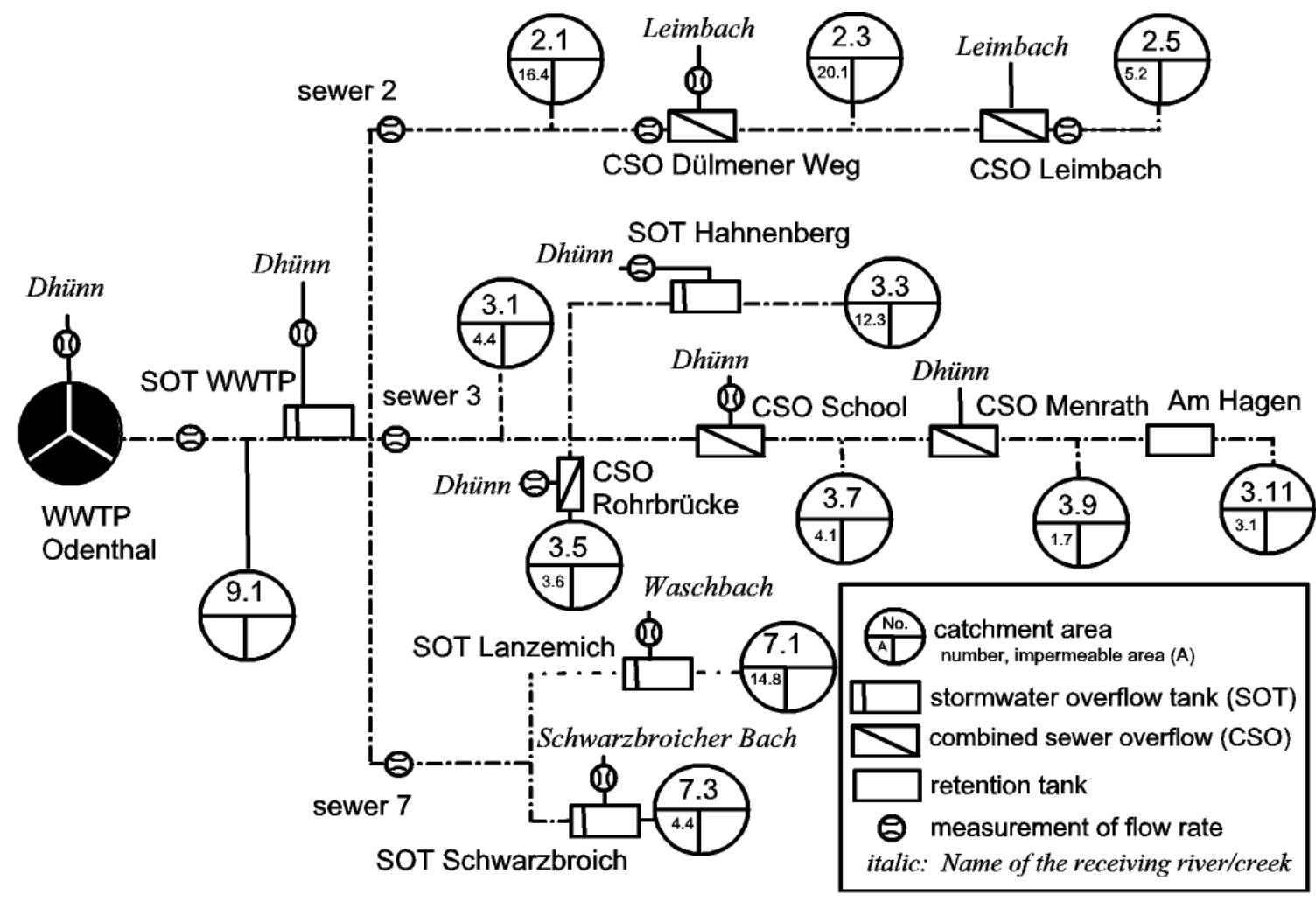

Figure 2. Overview of the measuring points in the Odenthal drainage system.

To help to assess the allowable contamination occurring in the receiving water, the results of the fish tests in the literature (e.g. Alabaster et al., 1979; Hamm, 1991; Haywood, 1983; Hvitved-Jacobsen, 1982; Jacob et al., 1984; Russo \& Thurston, 1977) were taken into account additionally. The data stock was completed by our investigations (Podraza et al., 2002) with fry released into the water upstream and downstream of the discharge points. The results enabled inferences to be made regarding the impact on the water contamination. Fish exhibit greater sensitivity to ammonia, nitrite, and dissolved oxygen than the other water fauna. As the Dhünn is to be classed as a potential stretch of salmon-spawning water, particularly stringent requirements have to be met in terms of water quality. Based on the above-mentioned data, immission-oriented threshold concentrations were deduced (Podraza et al., 2002; Orth et al., 2003). Tables 1 to 3 present these threshold concentrations for ammonia, nitrite, and dissolved oxygen, which are to be complied with in particular, but not only, downstream of the discharge points.

These threshold concentrations are based on the dose principle, i.e. the maximum concentration to which an organism can be exposed without this having a serious ad- verse effect depends on the duration and frequency of the exposure. The allowable concentration ensuing from a short surge of pollution may be far higher than that produced by pollution sustained over a long period. At the same time, the same pollutant concentration leads to a lower degree of damage if it rarely occurs than if it occurs frequently, so that threshold concentrations have to be formulated correspondingly more stringently if more frequent occurrence is involved.

Table 1. Threshold Ammonia Concentrations (in $\mathrm{mg} / \mathrm{L}$ ) for the River Dhünn, Depending on the Duration of Discharge (Exposure Period t in hours) and the Return Period $\left(\mathrm{T}_{r}\right.$ in years).

\begin{tabular}{lllll}
\hline & & \multicolumn{3}{l}{ Exposure Period (in hours) } \\
Return Period (in years) & $\mathrm{t}<1 \mathrm{~h}$ & $1 \mathrm{~h} \leq \mathrm{t} \leq 6 \mathrm{~h}$ & $\mathrm{t}>6 \mathrm{~h}$ \\
\hline $\mathrm{T}_{r}>2$ & seldom & $0.20 \mathrm{mg} / \mathrm{L}$ & $0.15 \mathrm{mg} / \mathrm{L}$ & $0.100 \mathrm{mg} / \mathrm{L}$ \\
$2 \geq \mathrm{T}_{r} \geq 0.25$ & medium & $0.15 \mathrm{mg} / \mathrm{L}$ & $0.04 \mathrm{mg} / \mathrm{L}$ & $0.020 \mathrm{mg} / \mathrm{L}$ \\
$\mathrm{T}_{r}<0.25$ & often & $0.10 \mathrm{mg} / \mathrm{L}$ & $0.02 \mathrm{mg} / \mathrm{L}$ & $0.002 \mathrm{mg} / \mathrm{L}$ \\
\hline
\end{tabular}


Table 2. Threshold Nitrite Concentrations (in $\mathrm{mg} / \mathrm{L}$ ) for the River Dhünn, Depending on the Duration of Discharge (Exposure Period $t$ in hours) and the Return Period $\left(\mathrm{T}_{r}\right.$ in years).

\begin{tabular}{lllll}
\hline & & \multicolumn{3}{l}{ Exposure Period (in hours) } \\
Return Period (in years) & $\mathrm{t}<1 \mathrm{~h}$ & $1 \mathrm{~h} \leq \mathrm{t} \leq 6 \mathrm{~h}$ & $\mathrm{t}>6 \mathrm{~h}$ \\
\hline $\mathrm{T}_{r}>2$ & seldom & $2.3 \mathrm{mg} / \mathrm{L}$ & $1.80 \mathrm{mg} / \mathrm{L}$ & $1.00 \mathrm{mg} / \mathrm{L}$ \\
$2 \geq \mathrm{T}_{r} \geq 0.25$ & medium & $1.5 \mathrm{mg} / \mathrm{L}$ & $1.00 \mathrm{mg} / \mathrm{L}$ & $0.05 \mathrm{mg} / \mathrm{L}$ \\
$\mathrm{T}_{r}<0.25$ & often & $0.3 \mathrm{mg} / \mathrm{L}$ & $0.15 \mathrm{mg} / \mathrm{L}$ & $0.05 \mathrm{mg} / \mathrm{L}$ \\
\hline
\end{tabular}

Table 3. Threshold Dissolved Oxygen Concentrations (in $\mathrm{mg} / \mathrm{L}$ ) for the River Dhünn, Depending on the Duration of Discharge (Exposure Period $t$ in hours) and the Return Period ( $\mathrm{T}_{r}$ in years).

\begin{tabular}{lllll}
\hline & & \multicolumn{3}{l}{ Exposure Period (in hours) } \\
Return Period (in years) & $\mathrm{t}<1 \mathrm{~h}$ & $1 \mathrm{~h} \leq \mathrm{t} \leq 6 \mathrm{~h}$ & $\mathrm{t}>6 \mathrm{~h}$ \\
\hline $\mathrm{T}_{r}>2$ & seldom & $2.5 \mathrm{mg} / \mathrm{L}$ & $4.0 \mathrm{mg} / \mathrm{L}$ & $5.0 \mathrm{mg} / \mathrm{L}$ \\
$2 \geq \mathrm{T}_{r} \geq 0.25$ & medium & $4.0 \mathrm{mg} / \mathrm{L}$ & $5.0 \mathrm{mg} / \mathrm{L}$ & $6.0 \mathrm{mg} / \mathrm{L}$ \\
$\mathrm{T}_{r}<0.25$ & often & $6.0 \mathrm{mg} / \mathrm{L}$ & $6.0 \mathrm{mg} / \mathrm{L}$ & $8.0 \mathrm{mg} / \mathrm{L}$ \\
\hline
\end{tabular}

Acute toxic exposure means exposure leading to a significant reduction in stocks of guide organisms even if only short-time occurrence ( $<1$ hour) is involved. A corresponding threshold concentration must not be exceeded at any time, especially downstream of discharge points, so that the criterion in this respect is the maximum concentrations occurring. At the same time, the actual level of the threshold concentration depends additionally on the frequency of occurrence and a distinction was made between three frequency levels. The return period $T_{r}>2$ years (frequency level $<0.5$ in $1 / \mathrm{yr}$ ) indicates that the corresponding concentrations are valid for events occurring less than once in two years. The return period $\mathrm{T}_{\mathrm{r}}<0.25$ years (frequency level $>4$ in $1 / \mathrm{yr}$ ) indicates that the corresponding threshold concentrations are valid for events occurring more often than four times in one year.

Nevertheless, a pollutant concentration lying considerably below the level of acute toxic exposure can have similarly serious effects if the exposure time is long enough. Leaving aside the fact that a habituation effect cannot be ruled out, maximum permissible concentrations, which must not be exceeded on a mean basis if chronic damage is to be avoided, can be arrived at in this respect, too. These concentrations are considerably lower than those for acute toxic exposure and, in the case at issue, have to be broken down again based on the exposure time. A distinction is made between an exposure duration level of one to six hours and one exceeding six hours. These threshold concentrations are additionally graduated depending on the frequency of occurrence, too. All in all, for each parameter, nine threshold con- centrations were derived from each of the three exposure duration and exposure frequency levels.

\section{Methods of Validating Compliance with the Threshold Concentrations}

The methods used to validate compliance with these threshold concentrations were sewer system simulations, dynamic treatment plant simulations, water quality simulations, and the pertaining measurements. However, for the following reasons, these instruments (models and measurements) cannot be used on their own, but only in a suitable combination:

- Evaluation of the readings enables the resultant water pollution levels to be established for individual events. However, the readings alone do not allow reliable conclusions to be drawn regarding the frequency of occurrence of the events in question.

- Based on the water quality model of the German Association for Water, Wastewater and Waste (ATV-DVWK) created as part of this Dhünn research project (Niemann et al., 2001; Wünsche \& Erbe, 2002), at the expense of a great deal of time and drawing on large quantities of data, qualitative statements can be made with regard to the repercussions of individual boundary conditions such as combined sewage discharges. As it is individual events that are described, statements regarding frequency are only possible to a very limited degree.

- The same applies to dynamic treatment plant simulations, which, like the water quality models, are primarily used to establish the repercussions of variations in individual boundary conditions in the course of time. Due to the complexity of the models and the large quantities of data required, this instrument is not suitable for a long-term simulation - at least, not at present.

- Pollutant load simulations, in the form of long-term simulations, are used as an instrument for evaluating the pollution discharged via the CSOs and SOTs. The results of the routinely-used pollutant load simulations yield no information on individual events, since the values calculated are, e.g. mean annual discharged pollutant loads and mean annual stormwater overflow rates, whereas degradation, sedimentation or remobilization processes are not taken into account. However, for the purpose of validating compliance with the evaluated threshold concentrations for water pollution, the concentrations relating to individual events are crucial.

To validate compliance with the threshold concentrations a hydrological sewer simulation model based on the program MOMENT ${ }^{\circledR}$ (B.G.S., 2001) was established and calibrated by means of the catchment area data, the local precipitation data and the flow rate readings. As a local precipitation measurement system has only been in existence 
for a two-year period, the precipitation data series used for the long-term simulation was that of a nearby station (Figure 1) recognized by the State Office for the Environment as being valid for the area of the municipality of Odenthal. The data are available for a period of 20 years.

The flow module of the sewer simulation model (MOMENT $^{\circledR}$ ) used for the purposes of the project enables the storm sewage overflow rates established on the basis of a hydrological model to be output in a resolution of five minutes for the entire period of the simulation. Comparison calculations using the hydrodynamic flow model DYNA ${ }^{\circledR}$ (Tandler, 2004) yielded comparable results for the area in question (high sewer slopes, few backwater zones) as far as flow rates are concerned.

To describe the degree of pollution, the concentrations recorded were analyzed to yield time dependent 90-percentile values (for the SOT "WWTP" and the CSO "School"). The range of the computed 90-pecentile values was proven to be valid by comparing the results with concentrations mentioned in the literature for similar circumstances (e.g. Brombach \& Fuchs, 2003; Brombach et al., 2004). Accordingly, this gives the pollutant concentrations of each of the two structures - CSO and SOT - in relation to the duration of the combined sewage overflow. Figure 3 shows the ammonium-concentration $\left(\mathrm{NH}_{4}-\mathrm{N}\right)$ measured for the CSO "School" during 16 storm sewage overflow events. Due to the sampling technique (15-minute composite samples, start of the sampling depending on the water level), the capacity of the automatic-samplers (maximum of 24 different samples during one overflow event) and the unequal durations of the storm sewage overflow events analyzed, the total number of readings for each time-step is different. The 90 -percentile values were then linked (on a time basis) with the simulated flow rates derived from the sewer flow model.

The $\mathrm{pH}$-value and temperature, which are essential for ammonium-ammonia dissociation $\left(\mathrm{NH}_{4}-\mathrm{N}-\mathrm{NH}_{3}-\mathrm{N}\right)$, were determined on the basis of the readings (mean values) and graduated according to the four seasons, the parameters based on separate quarterly values then being linked to the flow rates derived from the sewer flow simulation.

At the sewage system/treatment plant interface, the simulated rate of inflow derived from the sewer flow simulation was used. As, in the case of storm sewage, the inflow to the WWTP is limited to $2 \times$ DWF (dry weather flow), it is solely the initial characteristics and the duration of storm sewage inflow that are crucial to the treatment plant simulation. Based on the inflow pollutographs recorded for storm sewage inflows, the simulated flow rates, and the existing readings taken from the treatment plant outlet, the dynamic simulation allowed a realistic assessment to be made of the behaviour of the treatment plant during inflows of storm sewage.

Based on the results of the dynamic simulation and the readings in the treatment plant outlet, outflow pollutographs were inferred as a function of the rate of inflow on a seasonal basis (90-percentile values) to enable seasonally- induced changes in the behaviour of the treatment plant, due to the impact of temperature, to be taken into account. The pollutant loads discharged from the WWTP were determined by superimposing the simulated flow rates and the inferred outflow pollutographs. Any input variables additionally required, such as $\mathrm{pH}$-value and temperature in the outflow, were calculated as mean values of the readings, again, depending on the season.

On the basis of the extensive measurements, it was possible to ascertain the background concentrations $\left(\mathrm{NH}_{4}-\mathrm{N}\right.$, $\mathrm{NO}_{2}-\mathrm{N}$ and $\mathrm{BOD}_{5}$ ) and the $\mathrm{pH}$-value and temperature parameters of the water in the river. Likewise depending on the season. Based on the readings at the next water-level gauge located downstream of the catchment area, the 10-percentile values of the flow rate in the receiving water were calculated for the various seasons.

Taking into account the flow rates calculated and the pollutographs derived, at the CSOs, SOTs and the WWTP and the background concentration in the receiving water (Dhünn), it was now possible to determine, for each discharge point, the water pollution ensuing downstream. The long-term (20-year) precipitation data series served as an input variable.

The frequencies of occurrence were determined by evaluating the concentration values in the form of partial series (depending on the three duration stages). The partial series were assumed to be exponentially distributed. The assumption was proven using graphical analysis (McCuen, 1989). This made it possible to compare the concentrations occurring in the receiving water (Dhünn), depending on the level of duration and frequency of occurrence, with the threshold concentrations. As an example of the results obtained, the ammonia concentrations $\left(\mathrm{NH}_{3}-\mathrm{N}\right)$ calculated in the Dhünn downstream of the CSO "School" discharge point, depending on the frequency of occurrence and the duration level are shown in Figure 4.

\section{Planning Scenarios}

Mainly two scenarios - the actual design of the system and a newly developed, optimized system for the planning period up to 2020 - were investigated using the described combined approach. Based on the actual design of the sewer system and the WWTP, all discharges from the combined sewage system including the WWTP were tested to verify whether the threshold concentrations established are being complied with for the Dhünn as a stretch of salmonidspawning water. By way of an example, Figure 5 presents the nitrit parameter result for the CSO "School" (scenario: actual design of the system). Whereas no exceeding of the threshold concentrations for nitrite was established in respect of chronic pollutant levels, as regards discharge frequencies the $0.30 \mathrm{mg} / 1$ threshold concentration for acute toxic loads was exceeded by $9 \%$ as regards the frequency level $>41 / y r$. In this case, the threshold concentration can 


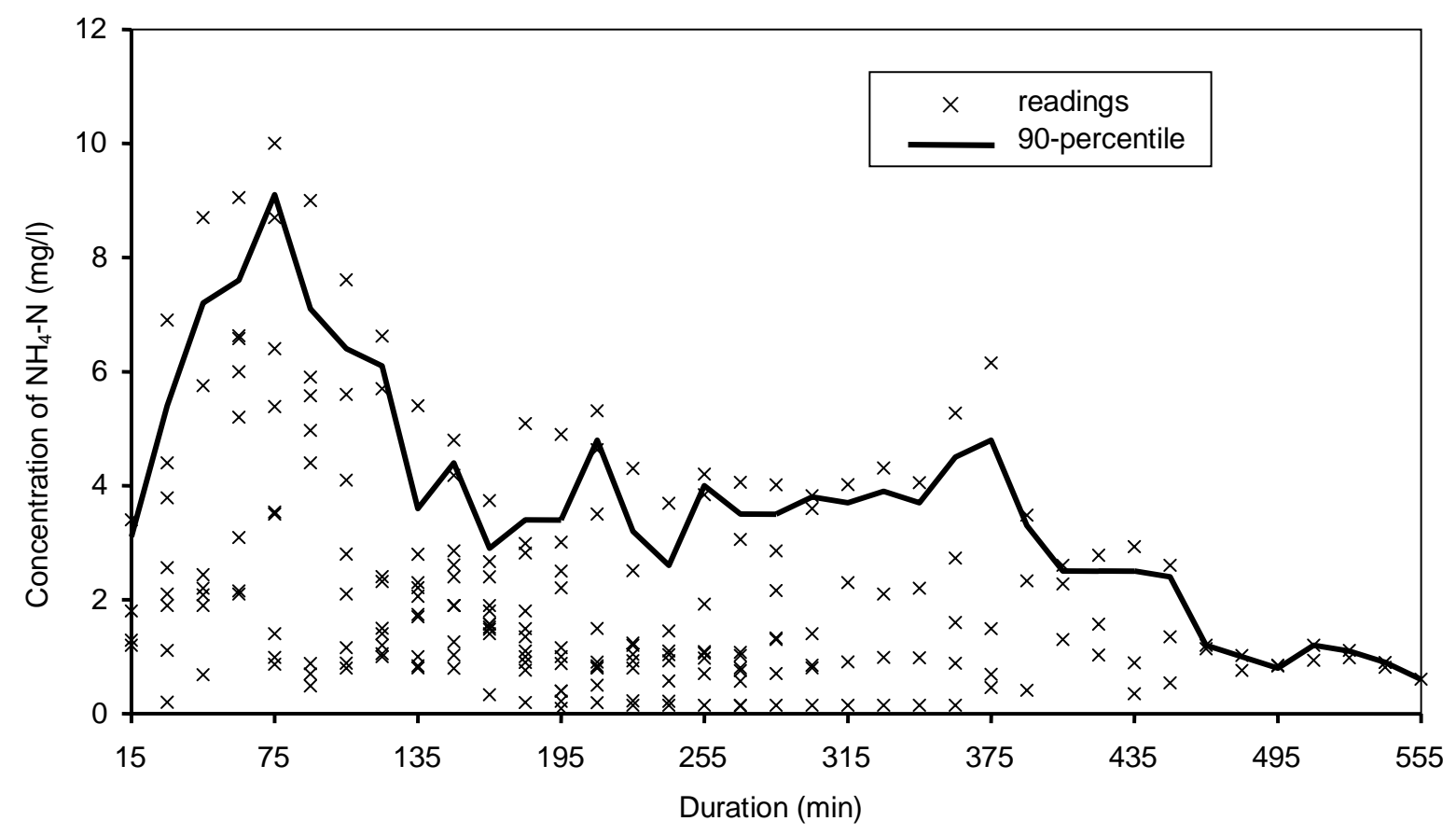

Figure 3. Concentrations of ammonium measured during 16 storm sewage overflow events and 90-percentile values calculated in relation to the duration of the storm sewage overflow events (for the CSO "School").

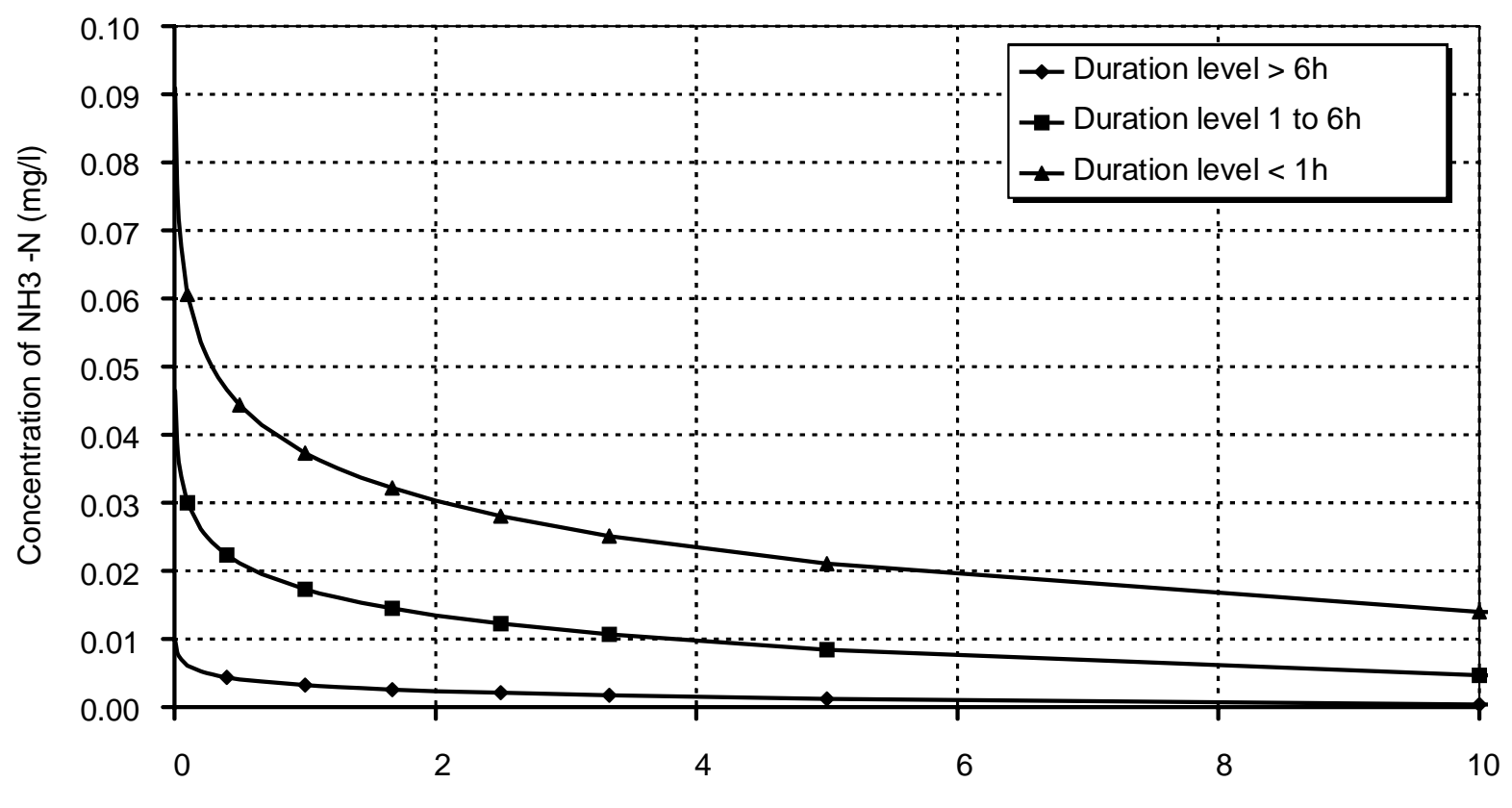

Frequency of occurrence (1/yr)

Figure 4. Ammonia concentrations (calculated) in the Dhünn downstream of the CSO "School" discharge point, relative to discharge frequency and duration level (exposure period) - scenario: actual design of the system. 
be complied with by adjusting the throttle at the CSO "School" (increase of flow rate to the stormwater tank and the WWTP located downstream in the sewer system). The (iterative) adjustment of the throttles in the system leads to a better utilization of the existent storage capacities and a reduction in the stormwater sewage volumes discharged.

With a view to developing an optimized overall system, a forecast was prepared based on the development of the Municipality up to the 2020 planning horizon. The question was also investigated as to the extent to which the water quality of the Dhünn would be influenced by "controlling" releases from the reservoir located upstream of the project area in a way that would reproduce the Dhünn's natural dynamic flow regime (lower releases in the summer months (critical case), higher releases in the winter and spring months). It appeared that, if this were done, the threshold concentrations would not be exceeded in the summer months as a result of combined sewage discharges.

\section{Conclusions}

In addition to compliance with the established river water quality standards (threshold concentrations) and the State of North Rhine-Westphalia's emission-orientated requirements regarding sewage systems and WWTPs, e.g. "Standard 128E" (ATV-DVWK, 1992), the primary objective was to minimize cost. As an expansion of the WWTP was absolutely essential, a modification of the planned expansion was developed that compensates for the construction of additional tank volume in the sewage system. This objective was attained by increasing the maximum permissible storm sewage inflow rate to above $2 \mathrm{x}$ DWF. This meant that although tank volume will have to be added to the treatment plant, considering the fact that an expansion is necessary in any case, this necessary increase in tank volume is considerably less expensive than having additional tank volume in the sewer system. In order to meet the requirements of "Standard 128E" (for the planning period up to 2020), assuming simultaneous compliance with the established river water quality standards - in terms of threshold concentrations - and in order to avoid further tank construction in the sewage system, the maximum permissible inflow to the WWTP has to be increased.

As demonstrated by the aerial photographs of the drainage area and the flow rate data recorded, the runoff-effective area proved to be considerably smaller than had been assumed in the previous planning operations. In combination with the adjustment of the throttles in the sewer system, this leads to a considerable reduction of the estimated cost, as the roughly $800 \mathrm{~m}^{3}$ of new tank volume (equivalent to $25 \%$ of the total existing volume), which had already been allowed for in the plans, is no longer needed. Willems et al. (1999) mentioned average specific costs of between $500 \mathrm{EUR} / \mathrm{m}^{3}$ and $1,250 \mathrm{EUR} / \mathrm{m}^{3}$ for a stormwater tank. The

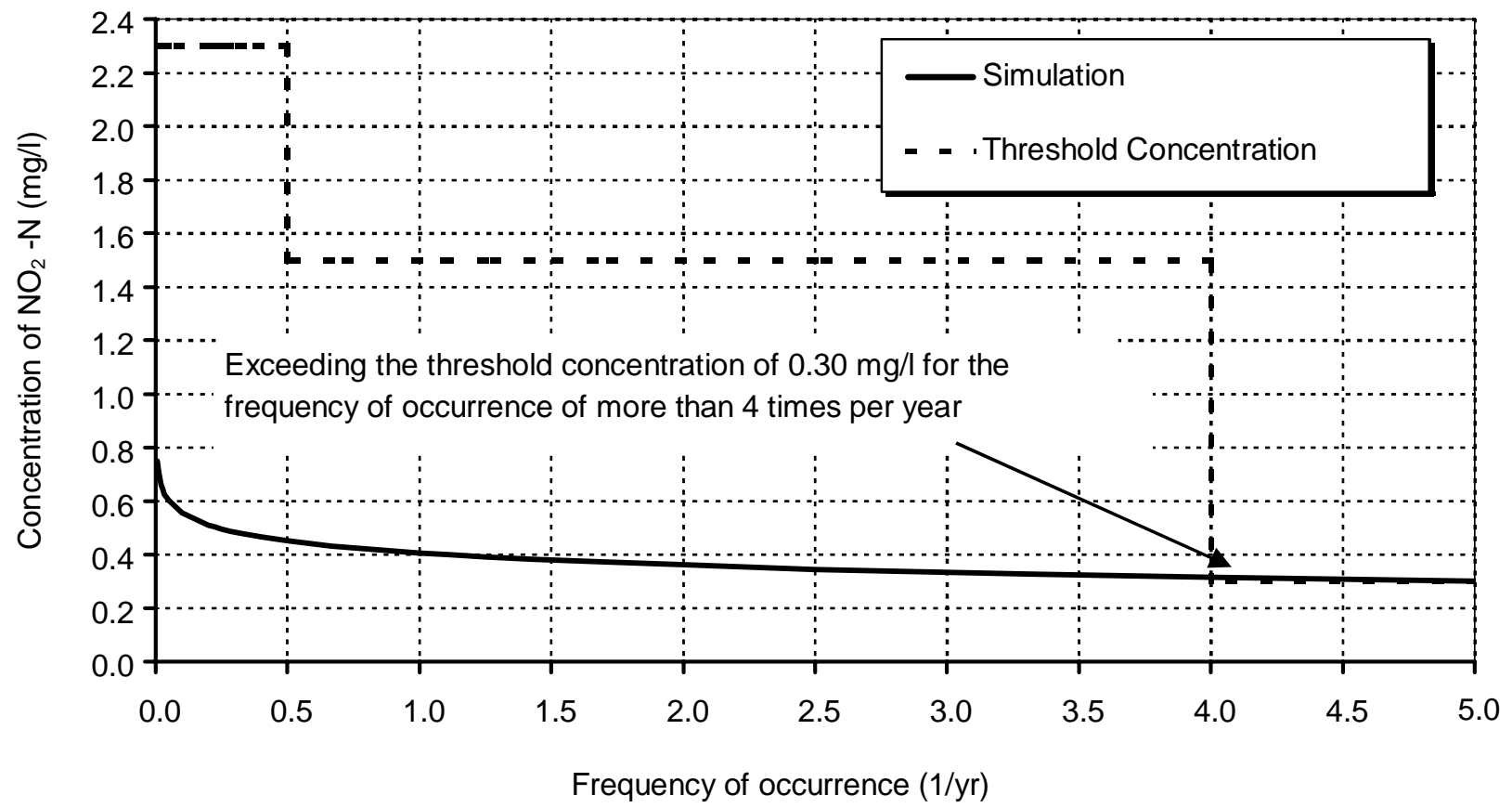

Figure 5. Nitrite concentrations (calculated) relative to the discharge frequency in the Dhünn downstream of the CSO "School" discharge point and threshold concentrations (duration level: $<1 \mathrm{~h}$ ) - scenario: actual design of the system. 
costs saved in this respect considerably exceed the expenses incurred by the measurements and the redesign work.

With this integrated and immission-based approach, design alternatives for the catchment area, the sewer system and the WWTP can be examined, bearing in mind the specific requirements of the receiving water, in order to improve water quality and to cut costs.

Acknowledgments. The financial support from the "Ministry of the Environment, Regional Planning and Agriculture" (MUNLV) of North Rhine-Westphalia is highly appreciated.

\section{References}

Alabaster, J.S., Shurben, D.G. and Knowles, G. (1979). The effect of dissolved oxygen and salinity on the toxicity of ammonia to smolts and salmon. Salmon salar L.-J. Fish Biol., 15, 705-712.

ATV-DVWK (1992). Standard ATV-A 128E, Dimensioning and Design of Stormwater Structures in Combined Sewers, German Association for Water, Wastewater and Waste (ATV-DVWK), Hennef, Germany.

BGS (2001). Spezialsoftware für die Wasserwirtschaft- Dokumentation des EDV-Programmsystems MOMENT, Brandt-Gerdes-Sitzmann Wasserwirtschaft GmbH, Darmstadt, Germany.

Brombach, H. and Fuchs, S. (2003). Datenpool gemessener Verschmutzungskonzentrationen in Misch-und Trennkanalisationen. KA Wasser-Abfall, 50(4), 441-450.

Brombach, H., Weiß, G. and Fuchs, S. (2004). Combined or separate sewer systems? A critical comparison using a new database on urban runoff pollution, in Proc. of the Fifth International Conference on Sustainable Techniques and Strategies in Urban Water Manaement, NOVATECH, Lyon, France.

Chocat, B., Krebs, P., Marsalek, J., Rauch, W. and Schilling, W. (2001). Urban drainage redefined: from stormwater removal to integrated management. Water Sci. Technol., 43(5), 61-68.

Crabtree, R., Milne, I. and Lindberg, S. (1998). Integrated simulation of urban catchment wastewater systems and receiving waters, Hydrology in a changing environment, Volume III, British Hydrological Society, UK.

FWR (1998). Manual-Urban Pollution Management, Second Edition, A planning guide for the management of urban wastewater discharges during wet weather, Foundation for Water Research (FWR), UK.

ESRI (2003). ArcGIS-The Complete Geographic Information System, ESRI, Redlands, California, USA.

Grüning, H. and Orth, H. (2001a). Control strategies for the optimisation of urban wastewater systems based on precipitation forecast, in Proc. of the Fourth International Conference on Innovative Technologies in Urban Storm Drainage-Novatech, Lyon, France, pp. 477-484.

Grüning, H. and Orth, H. (2001b). Investigations on the dynamic behaviour of the composition of combined sewage using on-line analysers, in Proc. of the First IWA Conference on Instrumentation, Control and Automation, Malmö, Sweden, pp. 139-146.

Grüning, H., Hoppe, H. and Weilandt, M. (2002). Integrated control strategies based on online measurements in sewer systems and WWTPs, in Proc. of the Third International Conference on Sewer Processes and Networks, IWA, INSA, CEREVE-ENPC, Paris, France, pp. 295-302.

Hamm, A. (1991). Studie über Wirkungen und Qualitätsziele von
Nährstoffen in Fließgewässern, Academia-Verlag, Sankt Augustin, Germany.

Harremoës, P. (2002). Integrated urban drainage, status and perspectives. Water Sci. Technol., 45(3), 1-10.

Haywood, G.P. (1983). Ammonia Toxicity in Teleost Fishes: A Review, Canadian Technical Report of Fisheries and Aquatic Sciences (1177).

Hvitved-Jacobsen, T. (1982). The impact of combined sewer overflows on the dissolved oxygen concentration of a river. Water Res., 16, 1099-1105.

IFAK (2003). SIMBA 4.0-Simulation of biological wastewater treatment, Reference, ifak system $\mathrm{GmbH}$. Magedeburg, Germany.

IWA (2000). Activated Sludge Models ASM1, ASM2, ASM2D and $A S M 3$, International Water Association (IWA) Task Group on mathematical modelling for design and operation of biological wastewater treatment, IWA Publishing, ISBN 1-900222-24-8.

Jacob, U., Walther, H. and Klenke, R. (1984). Aquatic insect larvae as indicators of limiting minimal contents of dissolved oxygen. Aquat. Insects, 6(3), 185-190.

Langeveld, J.G., Clemens, F.H.L.R. and van der Graaf, J.H.J.M. (2002), Increasing wastewater system performance - the importance of interactions between sewerage and wastewater treatment. Water Sci. Technol., 45(3), 45-52.

Mark, O., Tomicic, B., Hernebring, C. and Magnusson, P. (1999). Integrating catchment planning and management. Water Qual. Int., Jan./Feb., 23-26.

McCuen, R.H. (1989). Hydrologic Analysis and Design, PrenticeHall Inc., Englewood Cliffs, USA, ISBN 0-13-447954-8.

Niemann, A., Erbe, V., Weilandt, M. and Hoppe, H. (2001). Einsatz der Gewässergütesimulation für die Bewirtschaftungsplanung an kleinen Fliessgewässern- Beispiel Stadtentwässerung, Hamburger Berichte zur Siedlungswasserwirtschaft, Technische Universität Hamburg-Harburg, Germany, 33, pp. 143-155.

Orth, H., Hoppe, H., Weilandt, M., Londong, J., Böcker, K., Erbe,V ., Podraza, P. and Halle, M. (2003). Ein integriertes Gesamtkonzept für Entwässerungsgebiet, Kanalnetz, Kläranlage und Gewässer mit dem Ziel eines nachhaltigen Gewässerschutzes und einer Reduktion der Kosten, Project Report, RuhrUniversität Bochum, Germany.

Podraza, P., Halle, M., Müller, A. and Seuter, S. (2000). Limnoökologisches Screening im Rahmen des F.u.E.-Vorhabens "Integriertes Gesamtkonzept für Entwässerungsgebiet, Kanalnetz, Kläranlage und Gewässer mit dem Ziel eines nachhaltigen Gewässerschutzes und einer Reduktion der Kosten" der Ruhr-Universität Bochum, Project Report, umweltbüro essen, Essen, Germany.

Podraza, P., Halle, M., Müller, A. and Lautenschläger, M. (2002). Limnoökologische Hauptuntersuchung im Rahmen des F.u.E.Vorhabens "Integriertes Gesamtkonzept für Entwässerungsgebiet, Kanalnetz, Kläranlage und Gewässer mit dem Ziel eines nachhaltigen Gewässerschutzes und einer Reduktion der Kosten" der Ruhr-Universität Bochum, Project Report, umweltbüro essen, Essen, Germany.

Rauch, W., Bertrand-Krajewski, J.L., Krebs, P., Mark, O., Schilling, W., Schütze, M. and Vanrolleghem, P.A. (2002). Deterministic modelling of integrated urban drainage systems. Water Sci. Technol., 45(3), 81-94.

Russo, R.C. and Thurston, R.V. (1977). The acute toxicity of nitrite to fishes. US Environmental Protection Agency (EPA), Ecol. Res. Series, Recent Advances in Fish Toxicology, pp. 118-131. 
Schütze, M., Butler, D., and Beck, B. (1999). Optimisation of control strategies for the urban wastewater system - an integrated approach. Water Sci. Technol., 39(9), 209-219.

Schütze, M., Butler, D. and Beck, B. (2002). Modelling, Simulation and Control of Urban Wastewater Systems, Springer-Verlag, London Limited, UK, ISBN 1-85233-553-X.

Tandler(2004). Kanal++, The More Intelligent Problem Solution-Short Description, Environmental Informatics Ltd., Buch a. Erlbach, Germany. www.tandler.com.

Vollertsen, J., Hvitved-Jacobsen, T., Ujang, Z. and Talib, S.A. (2002). Integrated design of sewers and wastewater treatment plants. Water Sci. Technol., 46(9), 11-20.

Weilandt, M., Hoppe, H. and Orth, H. (2001). Betrieb von Messeinrichtungen zur Beurteilung von Mischwassereinleitungen, in Proc. of the workshop: Online-Messung in Kanalisation- snetzen. Mainz, Germany, Schriftenreihe Siedlungswasserwirtschaft, Ruhr-Universität Bochum, Ger- many, 40, pp. 33-49.

WFD (2000). Directive of the European Parliament and of the
Council 2000/60/EC establishing a framework for community action in the field of water policy. Official J. Eur. Communities, L 327, 1-73.

Willems, G., Rueschenberg, M. and Bode, H. (1999). Ausmass des Mischwasserrueckhalts bei der Niederschlagswasserbehandlung und die damit verbundenen Investitionskosten, in Proc. of the seventeenth Bochumer Workshop Siedlungswasserwirtschaft in Bochum, Germany, Schriftenreihe Siedlungswasserwirtschaft, Ruhr-Universität Bochum, Germany, 36, pp. 3-31.

Wünsche, C. and Erbe, V. (2002). Aufbau der Gütesimulation für die Dhünn mit dem ATV-FGSM im Rahmen des F.u.E.- Vorhabens "Integriertes Gesamtkonzept für Entwässerungs- gebiet, Kanalnetz, Kläranlage und Gewässer mit dem Ziel eines nachhaltigen Gewässerschutzes und einer Reduktion der Kosten" der Ruhr-Universität Bochum, Project Report, Wupperverbandsgesellschaft für integrale Wasserwirtschaft $\mathrm{mbH}$, Wuppertal, Germany. 